\title{
Development of personal and professional potential as an open self-organizing system during the study at the college
}

\author{
K. O. Moisieienko \\ $\mathrm{PhD}$ student of the department of the Social Psychology \\ Odesa Mechnikov National University, Ukraine \\ Corresponding author. E-mail: Karina.Moisieienko@gmail.com
}

Paper received 14.02.21; Accepted for publication 25.02.21.

\section{https://doi.org/10.31174/SEND-PP2021-247IX98-12}

\begin{abstract}
The article is devoted to the study of the development of personal and professional potential. The material characterizes the existing methodological approaches to this problem. On the basis of the existing theoretical approaches, the components of the development of personal and professional potential are identified. The article empirically shows the development of the personal and professional potential as an open self-organizing system. We can see the changes in the attitude of the personality, as well as the ways of perception of information, decision-making and interaction with the outside world between junior and senior students. The dynamics of the development of "Self-concept" among students of junior and senior courses is revealed.
\end{abstract}

Keywords: personality, potential, personal and professional potential, students, dynamic approach, self-organizing system.

Introduction. The study of personal and professional potential is a rather difficult task, since this concept is quite new in psychological science and does not have the same definition within the framework of existing psychological theories and schools. Based on the approaches we have studied, we propose the following structure of personal and professional potential: 1) The systematic approach; 2) Personal potential as an open self-organizing system; 3) Subjectivity as the basis of personal and professional potential; 4) The dynamic approach.

We cannot study a personality without considering it in a system of relationships. That is why we use a systematic approach to the study of personal and professional potential, where we include the individual characteristics of the personality, her abilities, professional orientation and life values and motives. To study personal and professional development, we turn to the idea of science as an open selforganizing system that allows us to consider the studied phenomena in the dynamics of its formation. This process can be represented as a gradual transformation of a person's thinking (with his characteristic individual characteristics) into professional thinking, which participates in ensuring the integrity and consistency of the emerging professional picture of the world and ensures self-development of his own personality. Subjectivity as the basis of personal and professional potential lies at the basis of our model, because the active life position of a person is an incentive force in the disclosure of potential opportunities. The main categories that determine the quality of personal and professional development are "maturity" and "professionalism". The use of a dynamic approach gives us the opportunity to observe the development of personal and professional potential and the features of its change.

All these principles are deeply interconnected and sometimes follow from one another as a consequence.

Literature review. The theoretical and methodological basis of the study is the psychological principles of the social determinism of mental processes, the unity of consciousness and activity, development and consistency, as well as the ideas of an integrative approach to the study of personality, laid down by B.G. Ananiev (O.S. Anisimov, K.A. Abulkhanova, A.A.Bodalev, A.A. Derkach, V.G.Zazykin, N.V. Kuzmina, I.N.Semenov and others). The analysis of the features of the manifestation of various levels of personal and professional potential is largely based on the provisions of modern psychological theories of personality (B.G. Ananiev, A.G. Asmolov, L.S.Vygotsky, V.S. Merlin, V.N. Myasishchev, K. K. Platonov, L. N. Sobchik, A. G. Shmelev, A. Adler, G. Aysenck, A. Bandura, R. Kettel, Z. Freud, E. Fromm, K. Horney, E. Erickson and etc.).

In the modern Ukrainian psychological science the study of potential is especially valuable work of V.I. Podshivaklina on social conditions and trends of the use of personal potential [4]; J.P. Virna of personal resources of professional adaptation; S.V. Sytnyk who considers personal potential as a condition of professional interaction [7]; A.E. Furman considers the self-concept; A.M. Bolshakova reveals the personal realization of man in ontogenesis; M.A. Sadova considers the psychological components of the potential of self-realization of the individual, which is very similar to the definition of the potential to V.I. Podshivalkina [3]; G.V. Deryabina considers the features of the manager's potential; S. Maksymenko introduces the term "human energy potential" as an indicator of a person's ability to act [1]; I. Manokha writes about the "potential of individual human existence" that reproduces the generalized signs of the development of the extraordinary nature of the "I" of man's during his life [2]; Y. Kalba introduces the term "gradual potential", which means structural and dynamic formation [5].

Summarizing the views of various authors, we conclude that personal and professional potential is a dynamic process and component of professional self-awareness, which affects the independence of professional choice of the subject, the formation of internal personality structures and their optimal use in activities, development of internal criteria self-assessment as a professional, finding personal meanings in work.

Purpose of the article. In this article, using a dynamic approach, we will reveal our personal and professional potential, using the principle of an open self-organizing system.

Materials and methods. The subject of our research is students of 1-5 courses of higher educational institutions. 90 students took part in our research. 45 subjects - students of 1-3 courses, and 45 people - students of 4-5 courses. Studying the development of personal and professional 
potential, we identified two main factors influencing the formation and development of the potential of an individual as an open self-organizing system: individual-typological characteristics of the personal potential and the personal-professional "I-concept".

To consider the individual-typological characteristics of the potential of the personality, we have identified 4 main directions of the personality: the potential for setting the personality to the external (extraversion) or internal (introversion) world; individual-typological features of the potential of an individual in the perception and processing of information; individual-typological features of the potential of an individual in decision-making; the potential for interaction of the individual with the outside world. This personality typology was proposed by I. Myers and K. Briggs. Therefore, to study the individual-typological characteristics of the personality as an open self-organizing system, we used the typological questionnaire MBTI.

For the study of the personal-professional "Self-concept" we took as a basis the methodology of E. Shein and his understanding of the professional Self-concept. We have identified the following components that make up the professional picture of the world: professional praxeology; trade-union stability; professional expertise; professional innovation; profession as part of life; social significance of the profession; profession as a field of self-realization; professional self-sufficiency.
Results. Let us consider the dynamics of the change in the attitude of the personality, as well as the ways of perceiving information, making decisions and interacting with the outside world between junior and senior students. Let's start by considering the potential of a person's attitude to the external or internal world. Looking at Figure 1, we can pay attention to the dynamics of changes in these indicators between junior and senior students. For 1-3-year students, the vector is more pronounced on the potential for setting a personality to the outside world $(\mathrm{M}=13.9$; $\mathrm{SD}=$ 4.7 ), and among students of 4-5 courses - on the potential for setting a personality on the inner world $(M=13,6$; SD $=5.1$ ). If we consider this phenomenon not only from the standpoint of extraversion and introversion, but from the standpoint of a personal and professional orientation, then we can come to the conclusion that junior students at the initial stage of their education are more directed towards external contacts: acquaintance with classmates, a feeling of "adulthood" and "freedom from parents." This is the time to establish new contacts with peers and the opportunity to establish oneself in a new educational institution. For senior students, there is a dynamic more towards selfreflection, they have already formed a circle of interests and acquaintances. They are focused on their research projects - preparation and defense of bachelor's or master's theses. It takes more effort and time to prepare.

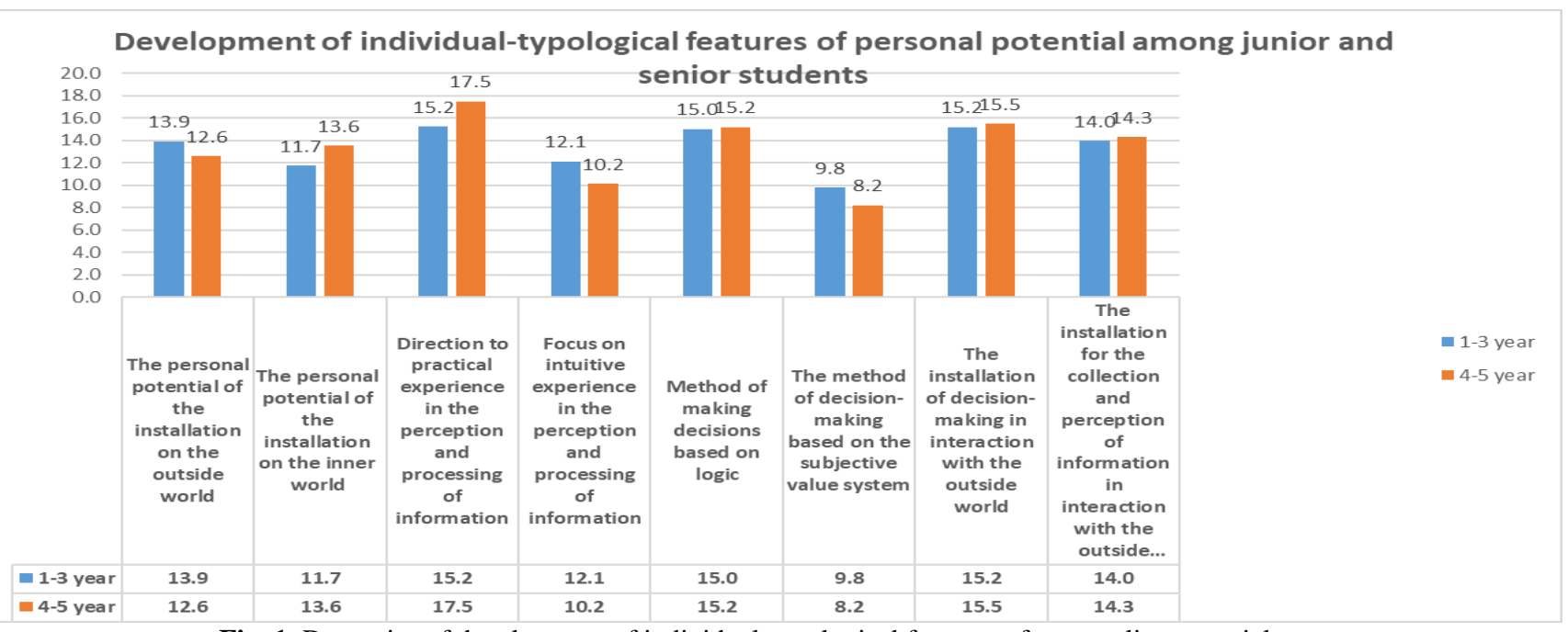

Fig. 1. Dynamics of development of individual-typological features of personality potential among junior and senior students

In both groups of students, the individual-typological characteristics of the personality's potential in the perception and processing of information are directed towards practical experience more than intuitive (1-3 courses: $\mathrm{M}=15.2 ; \mathrm{SD}=5.5 ; 4-5$ courses: $\mathrm{M}=17$, 5; $\mathrm{SD}$ = 4.3). However, for 4-5 year students, its indicator is higher by $\mathrm{M}=2.3$ than for 1-3 year students. Therefore, accordingly, comparing the indicators of the potential of the personality with the focus on intuitive experience in junior students, it turned out to be higher by $\mathrm{M}=2.1$ than among senior students (1-3 courses: $\mathrm{M}=12.1$; $\mathrm{SD}=4.4$; 4- 5 courses: $\mathrm{M}=10.2 ; \mathrm{SD}=3.4)$. Thus, we can say that among students in general, there is a dynamic of a general orientation towards practical experience. However, undergraduate students are more likely to rely on intuitive experience than undergraduate students. In our opinion, this may be due to the fact that 16-18-year-old young people still do not have sufficient life experience and practical knowledge, which is why they often have to intuitively perceive and process the information they receive in comparison with older students.

Individual-typological features of the potential of the individual in decision-making. Comparing the two groups of students, it can be seen that both groups are more inclined to make decisions based on logic than on the basis of a subjective system of values. However, again, as in the case of the perception and processing of information, junior students are more inclined to make decisions based on a subjective system of values than senior students (1-3 courses: $\mathrm{M}=9.8 ; \mathrm{SD}=4.4 ; 4-5$ courses: $\mathrm{M}=8.2 ; \mathrm{SD}=$ 3.6). We explain this in the same way as in the previous case - the lack of life experience and practical knowledge 
at the initial stage of the formation of personal and professional potential.

When analyzing the dynamics of the potential of interaction between a person and the outside world, we observe approximately the same indicators among junior and senior students. Both groups have approximately the same results between the decision-making mindset (1-3 courses: $\mathrm{M}=15.2 ; \mathrm{D}=4.8 ; 4-5$ courses: $\mathrm{M}=15.5 ; \mathrm{SD}=$ $4.4)$ and the collection mindset information when interacting with the outside world (1-3 courses: $\mathrm{M}=14.0$; $\mathrm{SD}=$ 5.0; $4-5$ courses: $\mathrm{M}=14.3 ; \mathrm{SD}=4.2$ ). Thus, we come to the conclusion that this potential is still at the stage of formation.

The dynamics of the development of "Self-concept" among junior and senior students. We also refer the development of the "Self-concept" to the principle of understanding a person as an open and self-organizing system. Let's consider in more detail the dynamics of change depending on the age of students.

Figure 2 shows that the overall picture of students in the formation of the "self-concept" is approximately the same. However, there are differences. And we can see how students' priorities change. For 1-3 year students, in the first place in terms of importance is the "Social significance of the profession" $(\mathrm{M}=7.7 ; \mathrm{SD}=1.9)$, and only then the factor "Profession as frequent of life" $(\mathrm{M}=7.6 ; \mathrm{SD}=1.5)$. And for 4-5 year students, they change places: in the first place in the priority "Profession as fraquent of life" $(\mathrm{M}=$ $7.8 ; \mathrm{SD}=1.3)$; and in second place: "Social significance of the profession" $(\mathrm{M}=7.1 ; \mathrm{SD}=2.0)$. That is, when young people enter university at the age of 16-17 and choose a professional activity, it is important for them that their future profession has meaning and social significance. However, other sides of life are also important for them: friends, family, hobbies and hobbies. This picture changes slightly for senior students. At the age of 19-21, the importance of professional development and obtaining a bachelor's or master's degree comes out on top. However, relationships are also becoming very important. Many students (mostly female) in 4-5 years build relationships and start families.

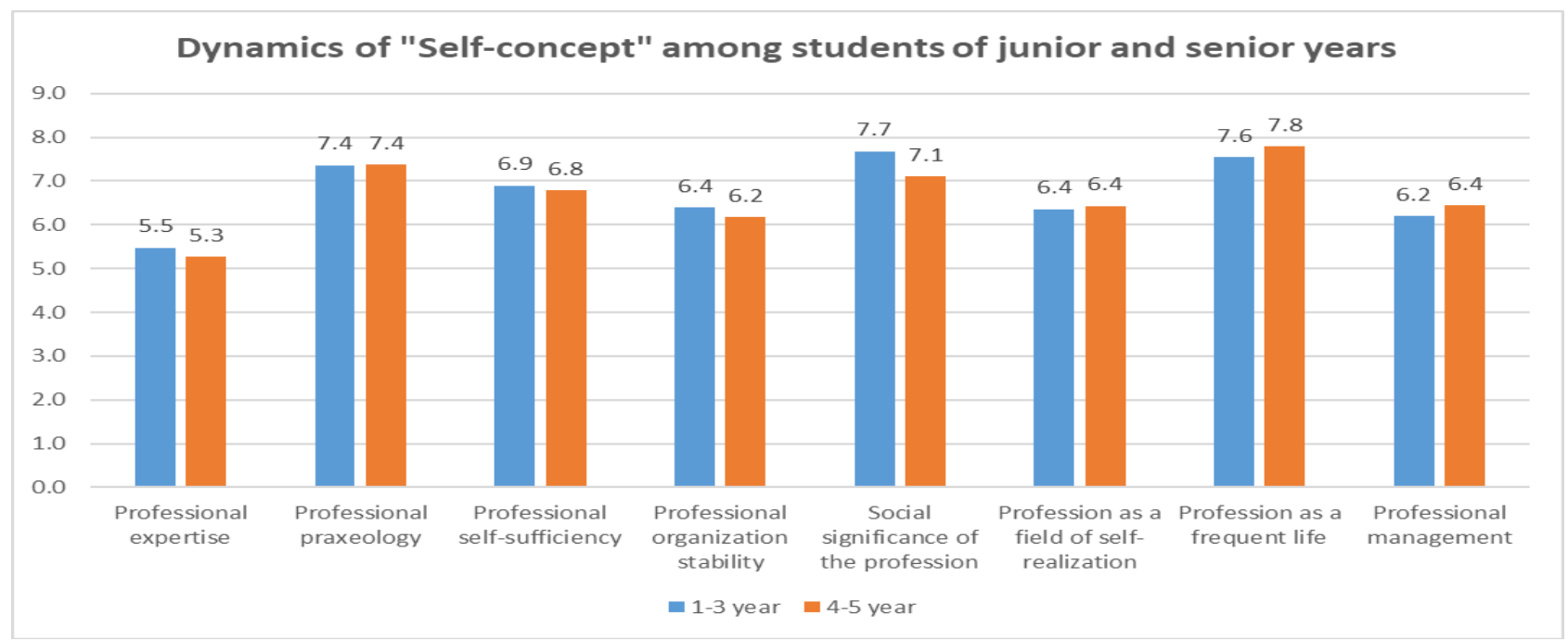

Fig. 2. Dynamics of "Self-concept" among students of junior and senior years

Thus, in the first place in their life is not only professional development, but also family values and relationships. That is, the factor "profession as a frequent life" becomes the main factor $(\mathrm{M}=7.8 ; \mathrm{SD}=1.3)$ And at the same time the social significance of the profession recedes into second place $(\mathrm{M}=7.1 ; \mathrm{SD}=2.0)$, decreasing from $\mathrm{M}=7.7$ to $\mathrm{M}=7.1$. Professional praxeology does not change during university studies. This value holds a fairly high position during the entire study at the university (1-3 courses: $\mathrm{M}=7.4 ; \mathrm{SD}=1.8 ; 4-5$ courses: $\mathrm{M}=7.4 ; \mathrm{SD}=2.1$ ). According to E. Shane's description, a person with such a career orientation "will consider that he has not achieved his career goals until he takes a position in which he can manage various aspects of the enterprise's activities: finance, marketing, production, development, sales" [8]. That is, in the understanding of students, the success of the realization of personal and professional potential depends on the position he occupies.

The dynamics of the indicator for "profession as a field of self-realization" during study at the university also does not change among students, but it is not a leading factor either (1-3 courses: $M=6.4 ; S D=1.7 ; 4-5$ courses: $M=$ 6.4 ; $\mathrm{SD}=1.6)$. The indicators of senior students decrease slightly compared to junior students for the following factors: Professional self-sufficiency (1-3 courses: $\mathrm{M}=$ 6.9; $\mathrm{SD}=1.6 ; 4-5$ courses: $\mathrm{M}=6.8$; $\mathrm{SD}=2.2)$; Professional organization stability (1-3 courses: $\mathrm{M}=6.4$; $\mathrm{SD}=$ 1.2; 4-5 courses: $\mathrm{M}=6.2$; $\mathrm{SD}=0.9)$; and Professional expertise $(1-3$ courses: $\mathrm{M}=5.5 ; \mathrm{SD}=1.5 ; 4-5$ courses: $\mathrm{M}=$ 5.3; $\mathrm{SD}=1.8$ ). In our opinion, of particular interest is the fact that "professional expertise" in the understanding of students is not one of the main factors. Moreover, it is in the last place in terms of importance.

We see small changes in the direction of growth among senior students according to the factor "Professional management" (1-3 courses: $\mathrm{M}=6.2 ; \mathrm{SD}=2.1 ; 4-5$ courses: $\mathrm{M}$ $=6.4 ; \mathrm{SD}=2,5)$.

Conclusions. We have shown the dynamics of change in the attitude of the individual, as well as the ways of perceiving information, making decisions and interacting with the outside world between students of junior and senior courses. Empirically we showed the dynamics of the development of the "self-concept" while studying at the university. Changes in priorities between the social significance of professional activity among junior students to the development of professional potential are shown only as a part of life among senior students. For senior students, the development is not only about professional potential, but 
also personal potential begins to take an important place in their activity and personal life. Thus, we observe the dynamics of the development of the structure of a special- professional potential. From which we can conclude that the personal and professional potential is dynamic and it is actively formed during study at the university.

\section{ЛИТЕРАТУРА}

1. Абульханова-Славская К. А. Деятельность и психология личности / Ксения Александровна Абульханова-Славская. - М.: Наука, 1980. - 335 с.

2. Ананьев Б. Г. Психологическая структура человека как субъекта / Борис Герасимович Ананьев. - 2. изд. - СПб. Питер, 1997. - 336 с

3. Кальба Я. Вчинковий потенціал особистості учня як предмет психологічного аналізу / Я. Кальба // Психологія і суспільство. - 2011. - №2. - С. 148-163.

4. Климов Е. А. Индивидуальный стиль деятельности в зависимости от типологических свойств нервной системы / Евгений Александрович Климов. - Казань : Мегапринт, 1969. - 207 c.

5. Климов Е. А. Психология профессионального самоопределения / Евгений Александрович Климов. - Ростов-наДону: Феникс, 1996. - 512 с.

6. Максименко С.Д. Генеза здійснення особистості / С.Д. Максименко. - К.: Видавництво ТОВ «КММ», 2006. - 240 c.

7. Максименко С.Д., В.І. Осьодло Стурктура та особистісні детермінанти професійної самореалізації суб'єкта. Проблеми сучасної психології 2010 №8 3 19

8. Маноха І.П. Психологія потенціалу індивідуального буття людини: онтологічно орієнтований підхід : автореф. дис. на здобуття наук. ступеня д-ра психол. наук: спец. 19.00.01 «Загальна психологія, історія психології» / І.П. Маноха. - К., 2003. - 48 c.

9. Міляєва В.Р. Теоретичний аналіз поняття «потенціал особистості»/ В.Р.Міляєва //Проблеми сучасної психології. 2013. -№20 - С.405-415

10. Подшивалкіна В. І. Соціальні умови та психологічні виміри тенденцій використання потенціалу особистості / В. Подшивалкіна // Психологія і суспільство. - 2009. №4. - С. 127-137.

11. Подшивалкина В. И. Жизненный путь и профессиональная карьера специалиста / Валентина Ивановна Подшивалкина. - Кишинев : Центральная типография, 1997.- 192 с.

12. Садова М.А. Психологічні складові потенціалу самореалізації особистості / М.А. Садова // Вісник Одеського національного університету. - 2010. -С.102-109.- (Серія: Психологія; Т.15; Вип. 9)

13. Ситнік С.В. Особистісний потенціал як умова професійної взаємодії/ С.В.Ситнік //Вісник ОНУ імені I.І.Мечникова.Психологія. -2012 -№8. -С.168-175

14. Титаренко Т.М. Життєвий світ особистості: у межах і за межами буденності / Тетяна Михайлівна Титаренко. - К. : Либідь, 2003. - 373c

15. Чикер В. А. Психологическая диагностика организации и персонала. - СПб.: Речь, 2004. - С. 85 - 96

\section{REFERENCES}

1. Abulchanova-Slavskaya, K.A. (1980). Activity and psychology of personality. Moscow.: ed. Nauka, 335 [In Russian]

2. Anan'ev, B.G. (1997). The psychological structure of a person as a subject. St.Petersburg: ed. Piter,336 [In Russian]

3. Chiker, V.A. (2004) Psychological diagnostics of the organization and personnel. St.Petersburg: ed. Rech, 85 - 96 [In Russian]

4. Kalba, Y. (2011). The action potential of the student's personality as a subject of psychological analysis. Psychology and society, 2, 148-163 [In Ukrainian]

5. Klimov E.A. (1969). Individual style of activity depending on the typological properties of the nervous system. Kazan: ed. Megaprint, 207 [In Russian]

6. Klimov E.A. (1996). Psychology of professional self-determination. Rostov-na_Donu: ed. Fenix, 512 [In Russian]

7. Maksimenko, S.D. (2006). The genesis of the personality implementation. Kyiv: ed. LLC "KMM" [in Ukrainian].

8. Maksimenko, S.D., Osedlo, V.I. (2010) Structure and personal determinants of professional self-realization of the subject. Problems of modern psychology, 8, 3-19[In Ukrainian]

9. Manocha, I.P. (2003). Psychology of the potential of individual human existence: an ontologically oriented approach. Extended abstract of Doctor's thesis. Kyiv [In Ukrainian]

10. Milyaeva, V.R. (2013). Theoretical analysis of the concept of "personality potential". Problems of modern psychology, 20, 405-415[In Ukrainian]

11. Podshivalkina V.I. (1997). Life path and professional career of a specialist. Kishinev: ed. Central Printing House, 192 [In Russian]

12. Podshivalkina, V.I. (2009). Social conditions and psychological dimensions of trends in the use of personal potential Psychology and society, 4, 127-137 [In Ukrainian]

13. Sadova, M.A. (2010). Psychological components of the selfrealization potential of the individual. Visnuk of Odessa national university, Vol. 15, 9, 102-109 [In Ukrainian]

14. Sutnik, S.V. (2012). Personal potential as a condition of professional interaction. Visnuk of Odessa national university, 8, 168-175 [In Ukrainian]

15. Titarenko T.M. (2003). The life world of the individual: within and outside of everyday life Титаренко. Kyiv: ed. Lubid, 373c [In Ukrainian] 